OPEN ACCESS

Edited by:

Adriano Pimentel,

Centro de Informação e Vigilância

Sismovulcânica dos Açores (CIVISA),

Portugal

Reviewed by:

J. Gregory Shellnutt,

National Taiwan Normal University,

Taiwan

Ian Ernest Masterman Smith,

The University of Auckland, New

Zealand

Dennis Geist,

National Science Foundation (NSF),

United States

*Correspondence:

Christoph Beier

christoph.beier@fau.de

Specialty section:

This article was submitted to

Petrology,

a section of the journal

Frontiers in Earth Science

Received: 15 June 2018

Accepted: 14 December 2018

Published: 04 January 2019

Citation:

Haase KM, Beier $C$ and Kemner $F$ (2019) A Comparison of the Magmatic

Evolution of Pacific Intraplate

Volcanoes: Constraints on Melting in

Mantle Plumes.

Front. Earth Sci. 6:242.

doi: 10.3389/feart.2018.00242

\section{A Comparison of the Magmatic Evolution of Pacific Intraplate Volcanoes: Constraints on Melting in Mantle Plumes}

\author{
Karsten M. Haase, Christoph Beier ${ }^{*}$ and Fabian Kemner \\ GeoZentrum Nordbayern, Friedrich-Alexander-Universität Erlangen-Nürnberg (FAU), Erlangen, Germany
}

The interaction of deep mantle plumes with lithospheric plates is one fundamental concept of plate tectonics. Based on observations mainly made on the Hawaiian volcanoes the compositional evolution of hotspot volcanoes is believed to reflect the variation of partial melting and source composition as the plate moves across the different melting zones of the mantle plume. The model predicts the formation of several magmatic stages that differ in composition. In order to test this model, we compare published compositional and age data from the intraplate volcanoes of the Hawaii, Society, Marquesas and Samoa hotspots on the older part of the Pacific Plate. The compiled data indicate that most volcanoes display variations within and between several magmatic series, and in most cases the more evolved lavas are associated with the voluminous shield stage. The Hawailan volcanoes show up to four different series ranging from tholeiites to nephelinites/melilitites, whereas the other hotspots mainly erupt two magmatic series consisting of transitional basalts and basanites. Submarine preshield stages at the Society and Marquesas hotspots resemble those observed at Hawaii. The large variation of primitive magmas in the Hawaiian plume as opposed to the other Pacific intraplate systems may reflect the higher temperatures, higher buoyancy flux, and extreme chemical heterogeneity at Hawaii. The shield stage activity at all four hotspots lasts for 1 million years indicating similar widths of the melting zone, although the temperatures of the distinct mantle plumes vary considerably. The relatively depleted shield stage magmatism typically overlaps by 200 kyrs with the formation of the more enriched postshield magmas indicating that the two melting and magma ascent systems exist contemporaneously.

Keywords: hawaii, samoa, society, marquesas, geochemistry, mantle melting, hotspots

\section{INTRODUCTION}

One of the fundamental features of the plate tectonic model is the interaction of lithospheric plates with so-called hotspots or melting anomalies that are likely caused by deep mantle plumes (Wilson, 1963; Morgan, 1971). Recent models suggest that there are different source regions from which deep mantle plumes ascend. They may either rise directly from the core-mantle boundary or from 
large low-velocity regions in the lower mantle (e.g., Courtillot et al., 2003; Jellinek and Manga, 2004; French and Romanowicz, 2015). The underlying assumption is that, during the period of most voluminous eruptions of the so-called shield stage, the active volcanic system is situated above the center of the melting anomaly providing the required excess heat, anomalously fertile (pyroxenite) rich mantle, and/or volatiles causing melting (e.g., Liu and Chase, 1991; Putirka et al., 2007; Herzberg and Asimov, 2008; Hofmann and Farnetani, 2013). As the plate moves across the mantle plume the degree and source of partial melting vary, leading to chemical and isotopic variations in the magmas feeding the volcanoes (Frey et al., 1990; Woodhead, 1992). Thus, age-progressive volcanic chains are formed with life-times of up to 80 million years (Duncan and Richards, 1991; Clouard and Bonneville, 2005) and, in some cases even exceeding 90 million years, e.g., at the Louisville seamount chain (Koppers et al., 2011). Within many of these chains the volcanoes seem to show a systematic compositional evolution ranging from tholeiitic to alkaline basalts with decreasing age (McDougall and Duncan, 1980; Woodhead, 1992). This magma evolution model is largely based on the Hawaiian volcanic chain because the Hawaii-Emperor Chain represents the best-studied plume track globally both from the subaerial and submarine edifices. According to the observations on the Hawaiian volcanoes four different magmatic stages were postulated to exist in intraplate volcanoes; (1) a preshield stage. (2) a shield stage. (3) a postshield stage, and (4) a rejuvenated stage (Clague and Dalrymple, 1987; Frey et al., 1990). The eruptive volumes increase through the preshield stage and reach a maximum during the shield stage when 80 to $95 \%$ of the entire volume of the volcano is produced. After the shield stage the erupted volumes decrease leading, in some cases, to several million years of volcanic quiescence before small volumes of lavas may erupt during the rejuvenated (or posterosional) stage (Clague and Dalrymple, 1987; Frey et al., 1990). The distinct Hawaiian eruption stages have been recently questioned because they are mainly based on subaerial sampling and volcanic evolution, and do not reflect gradual changes in magma compositions (Clague and Sherrod, 2014). According to the model, the magma composition of the hotspot volcanoes varies from highly $\mathrm{SiO}_{2}$-undersaturated preshield alkaline basalts to tholeiitic shield basalts and then again to alkaline $\mathrm{SiO}_{2}$-undersaturated postshield lavas. The mantle plume model suggests that the different stages reflect the different parts of the mantle plume. Little is known about the preshield stage because these lavas are probably covered by the later voluminous shield lavas, but this early stage indicates the arrival of the lithospheric plate at the edge of the melting anomaly. Increasing degrees of partial melting occur as the lithosphere moves across the mantle plume with the shield stage representing the largest degrees of melting in the plume center and the most voluminous volcanism. As the plate continues to move over the plume the degree of melting decreases during the postshield stage. The generation of the highly $\mathrm{SiO}_{2}$-undersaturated posterosional or rejuvenated stage magmas is not well-understood because many of these magmas form several million years after the plate passed the mantle plume (Garcia et al., 2010; Konter and Jackson, 2012). The duration of the shield stage and the composition of the magmas yield important insights into the composition, temperature and structure of the mantle plume and the melting processes. Additionally, the determination of the absolute plate velocities relative to mantle plumes depends on the understanding of the composition and duration of the shield stage (McDougall and Duncan, 1980). However, so far there has been little effort to compare the shield stages of volcanoes from different hotspots in order to define potential similarities and differences (Woodhead, 1992). Most recent studies have concentrated on the definition of mantle sources using radiogenic isotope compositions (e.g., Hofmann, 2003; Jackson and Dasgupta, 2008; White, 2010) but did not take into account the evolution of major and incompatible element compositions of the lavas on the scale of a single volcanic system.

Here, we compile and use the ages and compositions of lavas from the Hawaii, Society, Samoa, and Marquesas volcanic chains on the older portions of the Pacific Plate, where lithosphere thickness and motion should be comparable and thus similarities in magma genesis and duration of volcanism are expected. We selected these four hotspots because they are comparable in their setting and because many of their volcanoes are reasonably well-studied (see Supplementary Material). Indeed, we find very similar patterns of volcanic activity in all of these hotspots but we also note several features that are difficult to explain within the framework of the plume model. The Hawaiian plume is believed to represent the hottest mantle plume with the highest buoyancy flux on Earth (Davies, 1988; Sleep, 1990), yet the duration of shield volcanism in the other Pacific hotspots is similar ( $\sim 1$ million years) suggesting similar widths of the melting zones. Additionally, the Hawaiian hotspot volcanoes erupt lavas indicating both higher and lower degrees of partial melting than the other three hotspots investigated in this study which may indicate either a very heterogeneous nature of the mantle plume (including more pyroxenitic and carbonatitic sources), or more extreme melting conditions due to the higher temperature and a stronger buoyancy flux of the plume.

\section{GEOLOGICAL SETTING OF THE PACIFIC HOTSPOTS}

The Hawaii-Emperor chain of age-progressive volcanoes represents the type example of hotspot volcanism caused by a deep mantle plume (Wilson, 1963; Morgan, 1972). The Hawaiian intraplate volcanoes vary in size from the largest volcanic edifices on Earth with a height of some $10 \mathrm{~km}$ to much smaller volcanoes and accordingly, the volume estimates of the Hawaiian volcanoes range from 9,000 to $74,000 \mathrm{~km}^{3}$ (Clague and Sherrod, 2014). The Hawaiian Islands are the best-studied intraplate volcanoes on Earth and the Hawaii volcanic chain consists of 21 islands and several islets that show an age progression from SSE to NNW (e.g., Clague and Dalrymple, 1987; Sharp and Clague, 2006; O'Connor et al., 2013). The Hawaiian intraplate volcanoes lie on oceanic crust of Cretaceous age ranging from 87 to 94 million years (Detrick et al., 1981; Müller et al., 2008). The age progression of shield volcanism of the Hawaiian Islands implies an average velocity 
of the Pacific Plate of $10 \mathrm{~cm} / \mathrm{yr}$ across the plume (Clague and Sherrod, 2014). However, the exact rate of age progression may differ as a result of the plume moving south (Tarduno et al., 2003). Additionally, several volcanoes show volumetrically small stages of rejuvenated volcanism occurring up to 5.5 million years after initiation of the volcanism (Clague and Sherrod, 2014; Thordarson and Garcia, 2018). A strong buoyancy flux of Hawaii is reflected by large magma volumes as indicated by the size of the volcanic islands (Sleep, 1990). The present-day position of the front of the plume melting zone is beneath Loihi seamount $\sim 35 \mathrm{~km} \mathrm{SE}$ of the coast of Big Island (e.g., Moore et al., 1982; Watson and McKenzie, 1991). The detailed sampling of many Hawaiian volcanoes led to the model of four stages of magmatic evolution although much of this variation is based on subaerial lavas whereas submarine data have only recently been included into the existing model (Clague and Sherrod, 2014). The youngest Hawaiian volcanoes are in their shield or postshield stages and rejuvenated lavas are only known from Lanai, Molokai, Koolau, Kauai, and Niihau (Sinton et al., 2017; Thordarson and Garcia, 2018). The decreasing postshield magma production also leads to the establishment of magma reservoirs at the base of the crust, so that postshield lavas frequently are hawaiitic and mugearitic rather than basaltic in composition (e.g., Clague, 1987; Frey et al., 1990).

The Society Islands are part of French Polynesia, a region of an anomalously high rate of intraplate volcanism (Adam et al., 2010). Several aligned and age-progressive volcanoes form the $\sim 800 \mathrm{~km}$ long Society Island chain (Dymond, 1975; Guillou et al., 2005). The islands formed on late Cretaceous oceanic crust increasing in age from 66 million years at Mehetia in the southeast to 84 million years at Maupiti in the northwest of the island chain (Müller et al., 2008). The ages of the volcanism decrease from 4.5 million years at Maupiti to less than 0.3 million years at Mehetia yielding a velocity of 11.3 cm/yr for the Pacific Plate (Duncan et al., 1994; Uto et al., 2007). The best-studied island is Tahiti consisting of two volcanoes with stratigraphically defined and chemically distinct shield and postshield stages (Duncan et al., 1994; Hildenbrand et al., 2004). Other older volcanoes like Moorea and Huahine also consist of shield volcanoes with a caldera forming toward the end of the volcanism and later postshield lavas and intrusions (Guillou et al., 2005). The position of the present-day melting anomaly of the Society hotspot is located southeast of Tahiti evident from volcano-seismic activity at the submarine flanks of Mehetia and numerous submarine active volcanoes (Talandier and Okal, 1984; Devey et al., 1990; Binard et al., 1992).

The Marquesas volcanic chain consists of eight large islands between the about 5.0 to 5.5 million year-old Eiao in the NW, and the 1.0 to 1.5 million year-old Fatu Hiva in the southeast (Guillou et al., 2014). The youngest volcanism with ages $<0.5$ million years occurs at a seamount SE of Fatu Hiva (Desonie et al., 1993) and at the Marquesas Fracture Zone some $100 \mathrm{~km}$ south of Fatu Hiva (Révillon et al., 2017). The Pacific Plate moves with a velocity of $\sim 10.5 \mathrm{~cm} / \mathrm{yr}$ across the Marquesas mantle plume (McDougall and Duncan, 1980; Révillon et al., 2017) and lithospheric ages are on the order of 50 million years (Müller et al., 2008). The Marquesas islands consist of large shield volcanoes like, for example, the Tekao volcano on Nuku Hiva that have been suggested to mainly consist of olivine tholeiites (Guillou et al., 2014). These shield volcanoes frequently collapsed and the shield lavas were then covered by more incompatible element-enriched alkaline lavas, like the Taiohae formation on Nuku Hiva (Guillou et al., 2014). Similar patterns of volcanic evolution are observed at Ua Huka with the Hikitau shield volcano followed by the alkaline Hane lavas.

The Samoa volcanic chain is an $\sim 1,300 \mathrm{~km}$ long complex structure consisting of numerous seamounts and seven islands with the oldest ages of 13.2 million years occurring on the westernmost seamount and the youngest ages in the east, indicating a hotspot origin (Koppers et al., 2008, 2011). The age progression appears to be restricted to the shield volcanism of the Samoan chain whereas rejuvenated volcanism without systematic age progression occurs on many of the eastern islands (Natland, 1980; Koppers et al., 2011). The easternmost and youngest portion of the Samoan chain apparently consists of two parallel seamount chains with the youngest activity at the Vailulu'u submarine volcano in the north (Hart et al., 2000) and the Malu Malu volcano in the south (Koppers et al., 2011). The age variation along the chain suggest that the $\sim 100$ million yearold lithospheric plate moves at a velocity of $\sim 7.2 \mathrm{~cm} / \mathrm{yr}$ across the Samoa mantle plume (Koppers et al., 2008; McDougall, 2010). The volcanism of the Samoa Islands has been suggested to evolve from tholeiitic to mildly alkaline basalts to highly alkaline posterosional basalts, for example, on Upolu and Savai'i (Natland, 1980; McDougall, 2010) but the large volume of the late highly alkaline eruptions is notable (Konter and Jackson, 2012). The complex and abundant rejuvenated volcanism of the eastern Samoan chain is attributed to the geodynamic situation close to the Tonga subduction zone that may cause fracturing or flexuring of the lithosphere as well as additional mantle upwelling (e.g., Natland, 1980; Konter and Jackson, 2012; Strak and Schellart, 2018).

\section{RESULTS}

\section{The Comparison of the Compositional Variation of the Hotspot Lavas}

We compiled data on the age and chemical composition of lavas from volcanoes of the hotspots of Hawaii, Society, Marquesas, and Samoa (data sources can be found in the Supplementary Material), all situated on the older portion of the Pacific Plate (Figure 1). The total alkali-silica (TAS) classification of the lavas combined with the division line for tholeiitic and alkaline lavas from Hawaii (Macdonald and Katsura, 1964) reveals that only the Hawaiian volcanoes show a pronounced tholeiitic stage whereas the other three hotspots erupt mainly alkaline and transitional basalts and rare tholeiites (Figure 2). Many of the Hawaiian volcanoes like Kaua'i and Koolau show highly variable lava compositions ranging from tholeiitic basalts to basanites and nephelinites and melilitites (Figure 2a). Field observations combined with geochemistry suggest that all Hawaiian volcanoes evolve through a voluminous stage of tholeiitic eruptions followed by increasingly alkaline 


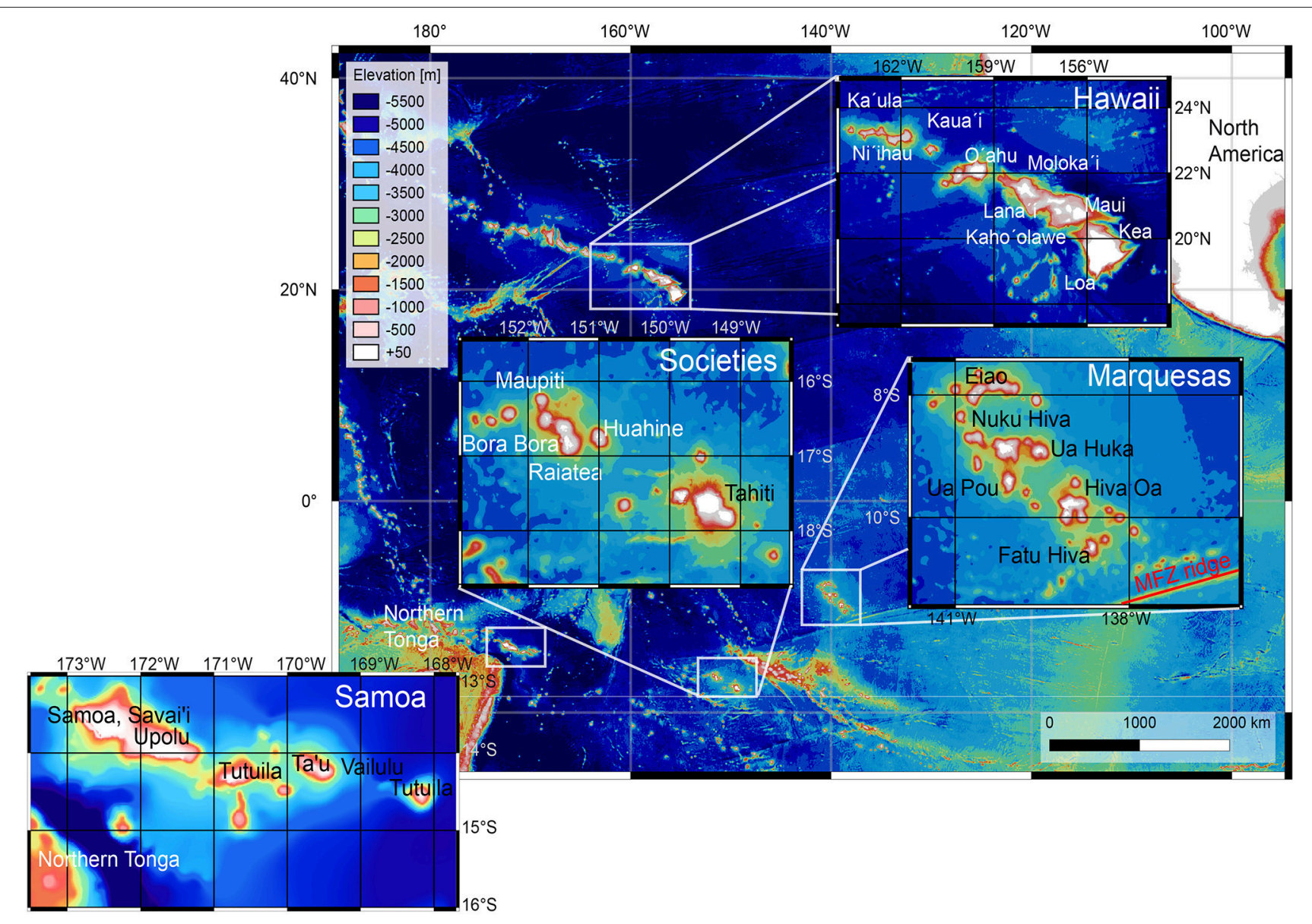

FIGURE 1 | Overview map of the Central and Northern Pacific including the Hawaiian, Marquesas, Samoa, and Society island chains.

lavas with alkali basalts, basanites, and nephelinites (Clague and Dalrymple, 1987). Additionally, Molokai and West Maui volcanoes erupted lavas that are significantly more evolved than the alkali basalts. The other hotspot volcanoes typically show variations between alkali basalts and basanites and most more evolved lavas are also related to the alkali basalts (Figure 2). The young volcanic edifices of the Society hotspot with the island Mehetia and the seamounts Teahitia and Rocard apparently consist of basanite and more evolved lavas like trachytes and phonolites. In contrast, alkali basalts and few tholeiites occur on Tahiti and older volcanoes like Maupiti, Moorea, and Huahine (Figure 2b).

The $\mathrm{Nb} / \mathrm{Zr}$ ratio has been widely used to distinguish the different magma series because these incompatible elements are not fractionated during crystallization processes (Figure 3) and are sensitive to source composition because $\mathrm{Nb} / \mathrm{Zr}$ correlates, for example, with $\mathrm{Sr}$ isotope ratios (Clague and Dalrymple, 1988). There is a broad negative correlation between the $\mathrm{SiO}_{2}$ content of the magmas and $\mathrm{Nb} / \mathrm{Zr}$, for example, in the Hawaiian lavas, where the tholeiites have the lowest $\mathrm{Nb} / \mathrm{Zr}$ and the alkaline magmas increasingly higher $\mathrm{Nb} / \mathrm{Zr}$ (Figure 3). Thus, although there are also differences in $\mathrm{Nb} / \mathrm{Zr}$ among the Hawaiian shield stage lavas
(Frey et al., 1994), the Hawaiian tholeiites in general have $\mathrm{Nb} / \mathrm{Zr}$ ratios of 0.05 to 0.11 (Figure 3a). The lavas with the lowest $\mathrm{Nb} / \mathrm{Zr}$ at the Society hotspot range from 0.09 to 0.16 , at the Marquesas islands between 0.08 to 0.14 , and at Samoa between 0.12 and 0.18 (Figure 3). The mafic lavas with lower $\mathrm{SiO}_{2}$ typically have higher $\mathrm{Nb} / \mathrm{Zr}$ and the most extreme $\mathrm{Nb} / \mathrm{Zr}$ of 0.38 are found in nephelinites and melilitites at Kaua'i volcano (Figure 3a). Basanites of the young Mehetia volcano in the Society hotspot have similar $\mathrm{Nb} / \mathrm{Zr}$ to the alkali basalts from the older volcanoes like Maupiti and Huahine (Figure 3b). On the other hand, the alkali basalts from the young Vailulu volcano in Samoa are much higher in $\mathrm{Nb} / \mathrm{Zr}$ than alkali basalts from the older volcanoes Ta'u and Tutuila (Figure 3d).

The range of $\mathrm{SiO}_{2}$ for primitive magmas with 12 to 15 wt.\% $\mathrm{MgO}$ varies considerably between the different hotspots (Figure 4). The control lines for addition of olivine with forsterite (Fo) contents of 88 are also shown because most lavas with $\mathrm{MgO}$ contents $>10 \mathrm{wt}$. $\%$ probably formed by addition, lavas with $\mathrm{MgO}<10 \mathrm{wt} . \%$ by fractionation of olivine ( \pm clinopyroxene and plagioclase). Primitive lavas $(\mathrm{MgO}>5 \mathrm{wt} . \%)$ of the Hawaiian volcanoes show a range from 36 to $52 \mathrm{wt} . \% \mathrm{SiO}_{2}$, whereas those of the Societies, Marquesas and Samoa all range from 41 to 48 wt.\% 

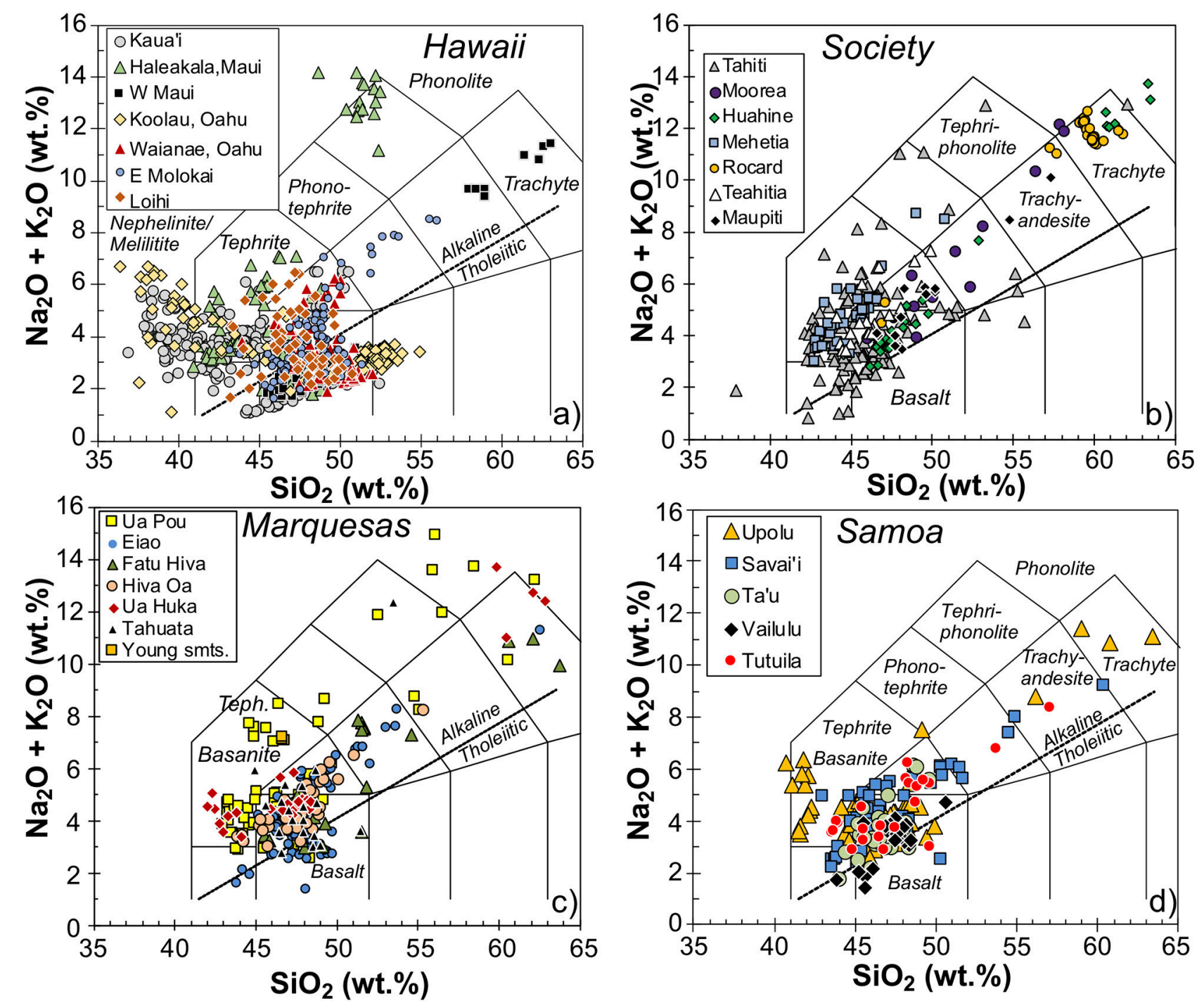

FIGURE 2 | The total alkalies-silica (TAS) diagram (Le Bas et al., 1986) for lavas from different volcanoes of the (a) Hawaiian, (b) Society, (c) Marquesas, and (d) Samoa hotspots. The dashed line shows the distinction between alkaline and tholeiitic lavas after Macdonald and Katsura (1964). Data sources can be found in the Supplementary Material.

$\mathrm{SiO}_{2}$ (Figure 4), i.e., they cover a much smaller range compared to Hawaii. Most volcanoes show well-defined increasing different trends of $\mathrm{SiO}_{2}$ with decreasing $\mathrm{MgO}$ implying parental magmas with different $\mathrm{SiO}_{2}$ contents.

The variation of incompatible element ratios with $\mathrm{SiO}_{2}$ is most pronounced in the chondrite-normalized $\mathrm{Ce} / \mathrm{Yb}$ ratios $\left[=(\mathrm{Ce} / \mathrm{Yb})_{\mathrm{N}}\right]$. The $(\mathrm{Ce} / \mathrm{Yb})_{\mathrm{N}}$ of the lavas from all hotspots display a negative correlation toward the lowest $\mathrm{SiO}_{2}$ contents of each volcano (Figure 5). This trend can be defined for the primitive Hawaiian lavas of Koolau volcano on Oahu and Kaua'i as $(\mathrm{Ce} / \mathrm{Yb})_{\mathrm{N}}=-2.5 \mathrm{xSiO}_{2}+115$. The correlation trend is plotted into the diagrams of the lavas from the other hotspot volcanoes for comparison. Whereas, many of the most primitive lavas of the Marquesas hotspot lie close to this trend, the Society and Samoa hotspot lavas have higher $(\mathrm{Ce} / \mathrm{Yb})_{\mathrm{N}}$ for a given $\mathrm{SiO}_{2}$ content (Figure 5) and lack an obvious correlation for the Society lavas.

\section{The Variation of the Chemical Composition With the Age}

$\mathrm{The} \mathrm{Nb} / \mathrm{Zr}$ ratios plotted against the age of the volcanism (Figure 6) reveal significant changes of lava composition with time in the Hawaii, Society and Marquesas hotspot volcanoes. Unfortunately, there are few samples with both geochemical and age data available from the Samoan hotspot so that we cannot show the variation with age for this hotspot. The earliest agedated stages of the different volcanoes typically have the lowest $\mathrm{Nb} / \mathrm{Zr}$ whereas later erupted lavas have higher $\mathrm{Nb} / \mathrm{Zr}$ ratios (Figure 6). We interpret this to represent the transition from the 

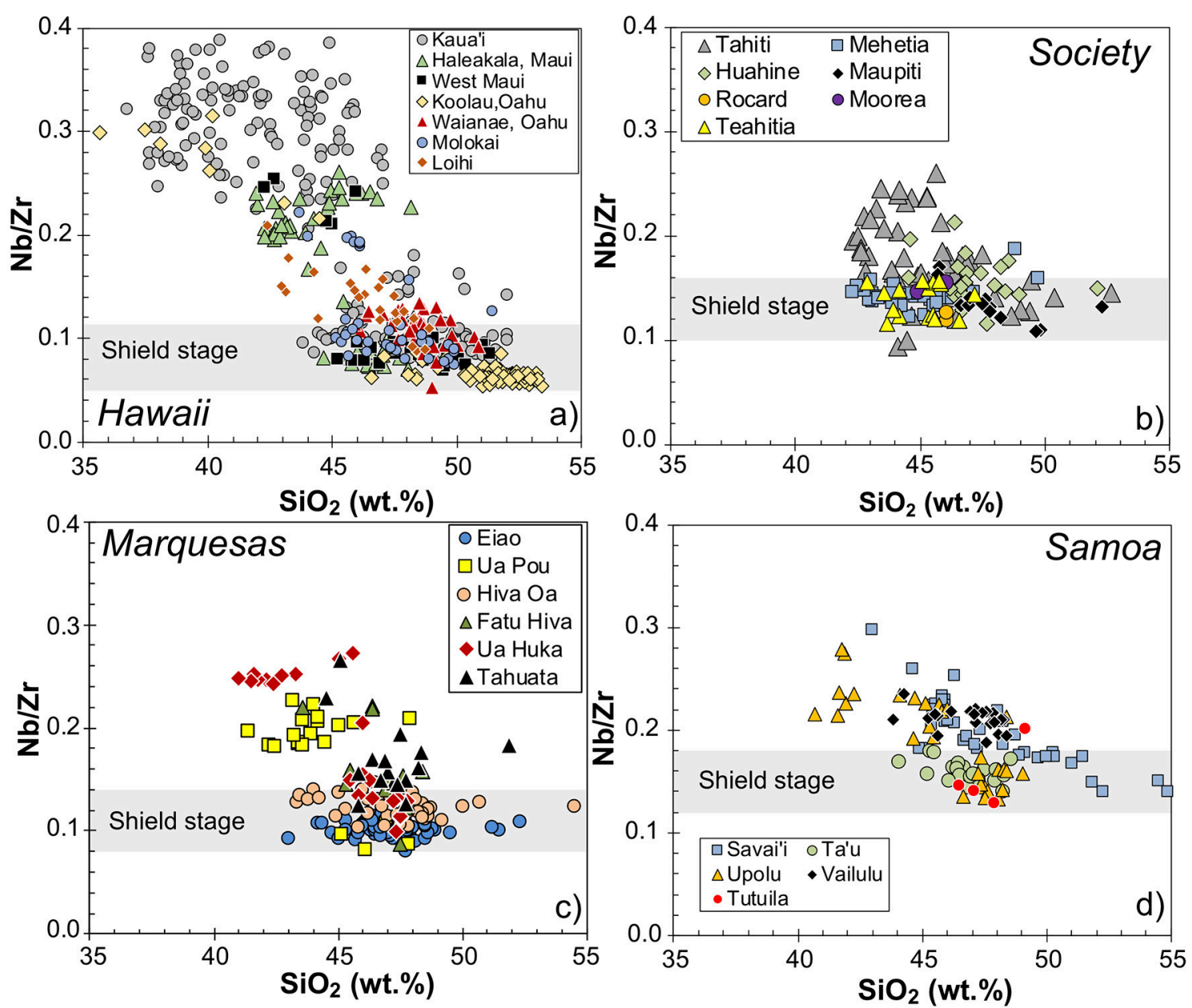

FIGURE 3 | The variation of $\mathrm{Nb} / \mathrm{Zr}$ ratios with $\mathrm{SiO}_{2}$ contents for the lavas from the (a) Hawaiian, (b) Society, (c) Marquesas, and (d) Samoa hotspots. The Nb/Zr ratio remains constant during much of the magma evolution and is generally not affected by fractional crystallization. The differences of Nb/Zr ratios in lavas from the same volcanoes reflect different magma series of volcanic stages. The lavas with the lowest Nb/Zr typically represent the shield stage as outlined by the gray bars. Data sources can be found in the Supplementary Material.

shield to the postshield stage that often appears to be gradual, for example, at West Maui, Tahiti, and Tahuata (Figure 6). We cannot define the timing at which the preshield stages changed to shield volcanism because of a lack of coexisting preshield lavas for the shield and postshield stages shown here. However, the duration of the shield stage as indicated by the occurrence of lavas with low $\mathrm{Nb} / \mathrm{Zr}$ can be defined to be on the order of 1 million years in the case of West Maui, Koolau, and Kaua'i in the Hawaiian hotspot (Figure 6a). The shield stage appears to last for similar periods of time at the well-studied volcanoes of Tahiti in the Societies, and Tahuata and Ua Huka in the Marquesas. Toward the end of the shield stage defined by the low $\mathrm{Nb} / \mathrm{Zr}$ ratios, volcanoes at all three hotspots show a coeval eruption of more enriched lavas with an overlap of several 100 kyrs (Figure 6). In the case of Hawaiian volcanoes and the Tahiti and Huahine volcanoes in the Societies the change to more enriched postshield lavas is relatively small. The Hawaii data display the large age and compositional difference of the rejuvenated lavas compared to the shield and postshield lavas (Figure 6a). The relatively well-studied volcanoes in the Marquesas show a similar pattern with much higher $\mathrm{Nb} / \mathrm{Zr}$ lavas erupting after a 1 million year-long break at Ua Huka whereas the rejuvenated lavas at Fatu Hiva and Tahuata erupt subsequent to the shield and postshield stage (Figure 6c).

\section{DISCUSSION}

\section{The Compositional Variation of the Submarine Preshield Volcanic Stage}

Because the preshield stage of the oceanic intraplate volcanism at hotspots occurs at great water depths and are covered by the younger stages, little is known about these eruptions and the composition of the lavas. Basanitic to tholeiitic basalts were recovered from Loihi seamount SE of the island of Hawaii (Figure 2a) and these lavas were interpreted to reflect initiation of melting at the plume edge beneath the lithosphere (Moore 

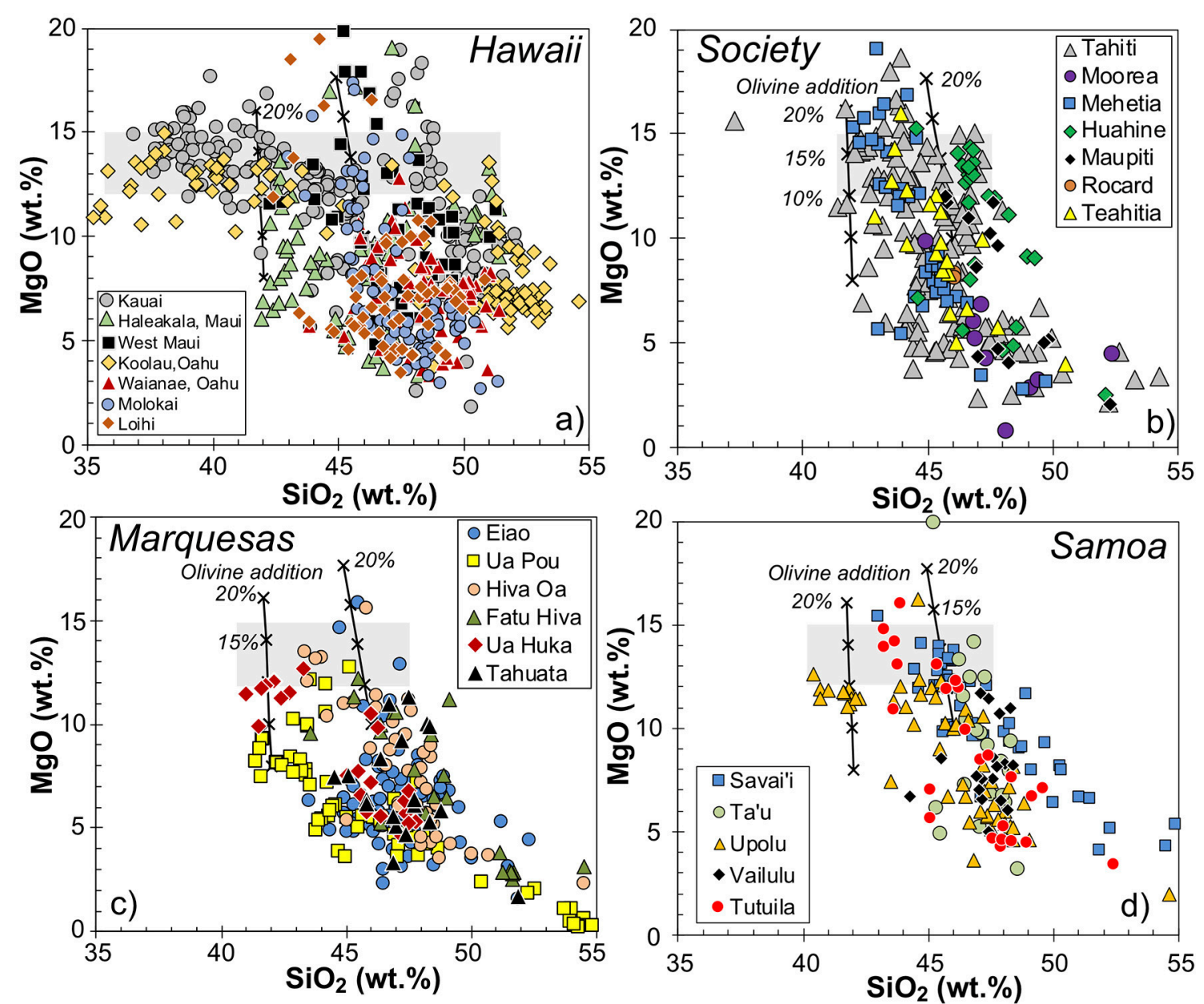

FIGURE 4 | The variation of $\mathrm{SiO}_{2}$ vs. MgO contents in the lavas from the (a) Hawaiian, (b) Society, (c) Marquesas, and (d) Samoa hotspots. The SiO 2 contents typically increase with decreasing $\mathrm{MgO}$ due to crystal fractionation processes. Lavas with 12-15 wt.\% MgO represent near-primary compositions of magmas from the mantle and their range is indicated by the gray box. Note that the Hawaiian volcanoes show a much larger range of $\mathrm{SiO}_{2} \mathrm{contents}(36-52$ wt. $\%)$ for these primary magmas than the other hotspots (41-48 wt.\%). The two black lines show the addition of olivine with forsterite (Fo) contents of 88 in $5 \%$ increments indicated by the crosses. Data sources can be found in the Supplementary Material.

et al., 1982). Clague and Sherrod (2014) suggest that preshield lavas can be observed at the four Hawaiian volcanoes Loihi, Kilauea, Kohala, and perhaps Hualalai, whereas lavas of this stage are buried at most other volcanoes. The submarine young volcanoes at the other three studied hotspots also differ from the subaerial lavas. At the Society hotspot, lavas at the young Mehetia and Teahitia volcanoes are more $\mathrm{SiO}_{2}$-undersaturated basanites than the subaerial alkali basalts of Tahiti, Huahine, or Moorea (Figure 2b) although the $\mathrm{Nb} / \mathrm{Zr}$ ratios are similar (Figure $\mathbf{3 b}$ ). Both the submarine and subaerial lavas recovered from the youngest island Mehetia are basanites (Figure $\mathbf{2 b}$ ) indicating that the volcano may still be in the preshield stage of volcanism of the Society hotspot. Thus, similarly to the case in Hawaii, the young preshield alkaline melts may have formed by lower degrees of melting than the transitional basalts of the later subaerial shield stage. Devey et al. (2003) suggested that the preshield stage at the Society hotspot formed by melting of the most incompatible element-enriched source which could explain the high $\mathrm{Nb} / \mathrm{Zr}$ ratios. Additionally, the small preshield volcanoes at the Society hotspot like Rocard erupted relatively evolved lavas with trachytic composition (Figure $\mathbf{2 b}$ ) indicating longer times of stagnation in the lithosphere before a stable magma system with larger volumes of magma is established (Devey et al., 2003). Little is known about the youngest volcanism of the Marquesas hotspot because this volcanism occurs at the submarine Marquesas Fracture Zone but the lavas recovered from two small young seamounts are tephritic (Révillon et al., 2017), i.e., more alkaline than the alkali basalts of the Marquesas shield stage lavas (Figure 2c). In contrast, the lavas from the young submarine Vailulu volcano at the eastern end of the Samoan chain have similar transitional basaltic compositions to those from the older subaerial volcanoes (Figure 2d) but higher $\mathrm{Nb} / \mathrm{Zr}$ (Figure 3d). Thus, with the exception of Samoa the preshield submarine volcanism at the three hotspots of Hawaii, Society and Marquesas appears to be more alkaline 

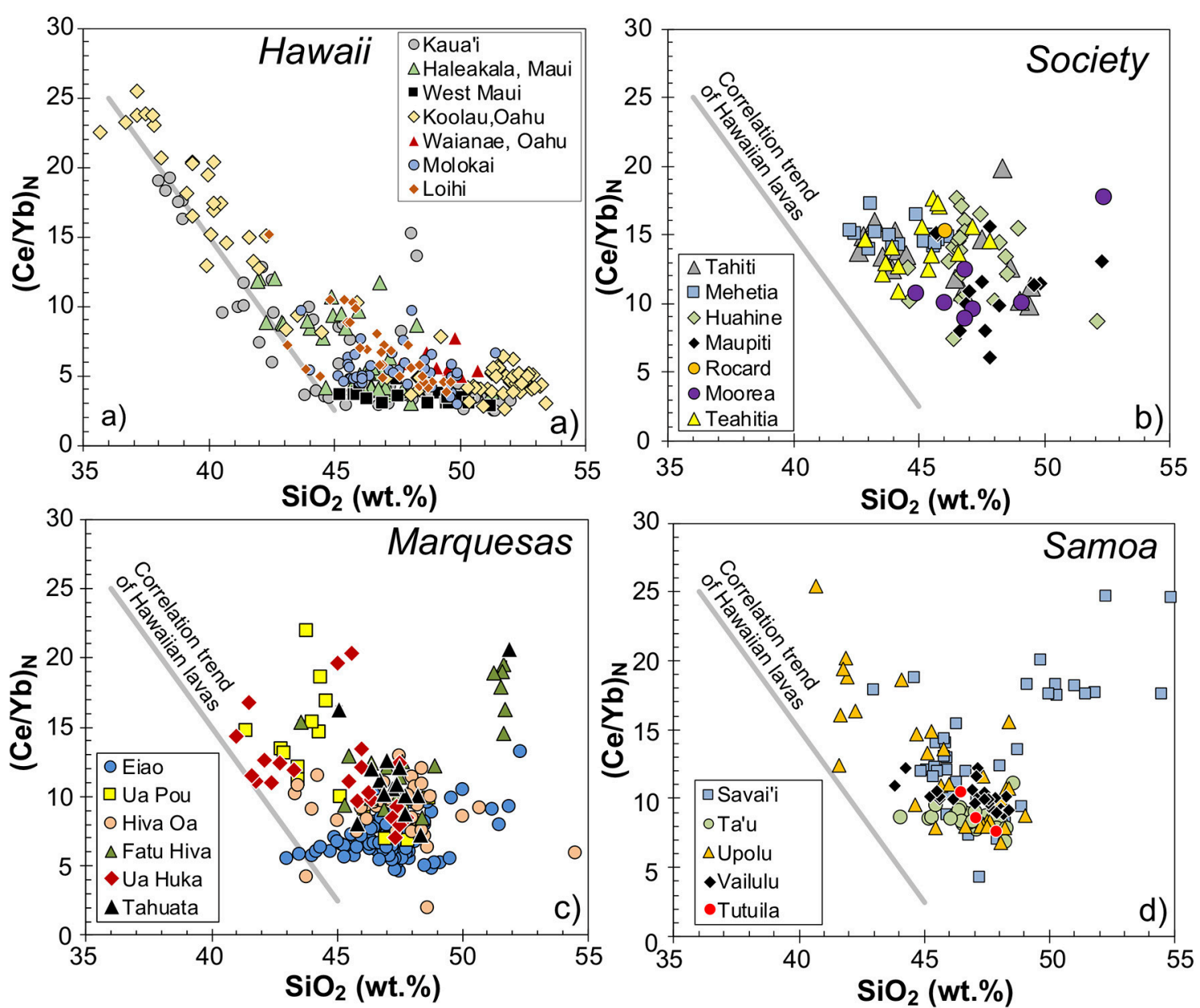

FIGURE 5 | The variation of chondrite-normalized $\mathrm{Ce} / \mathrm{Yb}$ ratios with $\mathrm{SiO}_{2}$ contents of the lavas from the (a) Hawaiian, (b) Society, (c) Marquesas, and (d) Samoa hotspots. Note that there is a negative correlation between the $(\mathrm{Ce} / \mathrm{Yb})_{\mathrm{N}}$ and the lowest $\mathrm{SiO}_{2}$ content. Different magma series have relatively constant $(\mathrm{Ce} / \mathrm{Yb})_{\mathrm{N}}$ but crystal fractionation leads to increasing $\mathrm{SiO}_{2}$ contents. The average trend of the variation observed at Koolau and Kaua'i is shown in all diagrams for comparison. Data sources can be found in the Supplementary Material.

than the later subaerial shield stages which probably indicates lower degrees of partial melting during the earliest volcanic stage.

\section{Variation of Shield Stage Lava Compositions}

The shield stage of a volcano is generally defined by structural and stratigraphic observations of the most voluminous eruptive stage yielding 85 to $90 \%$ of a volcano (Clague and Sherrod, 2014). The observations at the subaerial parts of the volcanoes indicate that tholeiitic basalts erupt during the shield stage but that there is a chemical transition to the alkaline postshield stage (e.g., Chen et al., 1991; Sinton et al., 2017). The tholeiitic basalts of the Hawaiian shield stage have the lowest $\mathrm{Nb} / \mathrm{Zr}$ ratios of all Hawaiian lavas (Figure 3a) which was pointed out previously (Clague and Dalrymple, 1988; Frey et al., 1994). The well-studied shield lavas in the Hawaiian volcanoes are tholeiitic basalts but in the other hotspots the shield lavas are tholeiitic to alkali basaltic (Figure 2). The shield lavas of Tahiti are relatively well-defined based on field observations and a well-dated $\sim 1$ million year-long stage with eruption of transitional basaltic lavas with relatively low $\mathrm{Nb} / \mathrm{Zr}$ (Figure 6). Similarly, Moorea and Huahine volcanoes in the Society hotspot largely consist of transitional basalts that lie on the division line in Figure 2 and are interpreted as shield stage lavas. We suggest that all shield stage lavas of the studied Pacific hotspot volcanoes are typically the least incompatible element-enriched samples, i.e., those with the lowest alkali content, $\mathrm{Nb} / \mathrm{Zr}$ and $(\mathrm{Ce} / \mathrm{Yb})_{\mathrm{N}}$ but they also display relatively high $\mathrm{SiO}_{2}$ contents (Figures 2-4, 6). Whereas, the variable $\mathrm{SiO}_{2}$ content largely reflects differences in degree and mean pressure of melting (Green et al., 2001), the incompatible element ratios mainly reflect differences in composition of the mantle source composition (Frey et al., 1978). Thus, we conclude in agreement with previous studies (e.g., Frey et al., 1991; Duncan et al., 1994; Farnetani and Hofmann, 2010) that the shield stage of the different hotspot volcanoes represents the highest degrees 

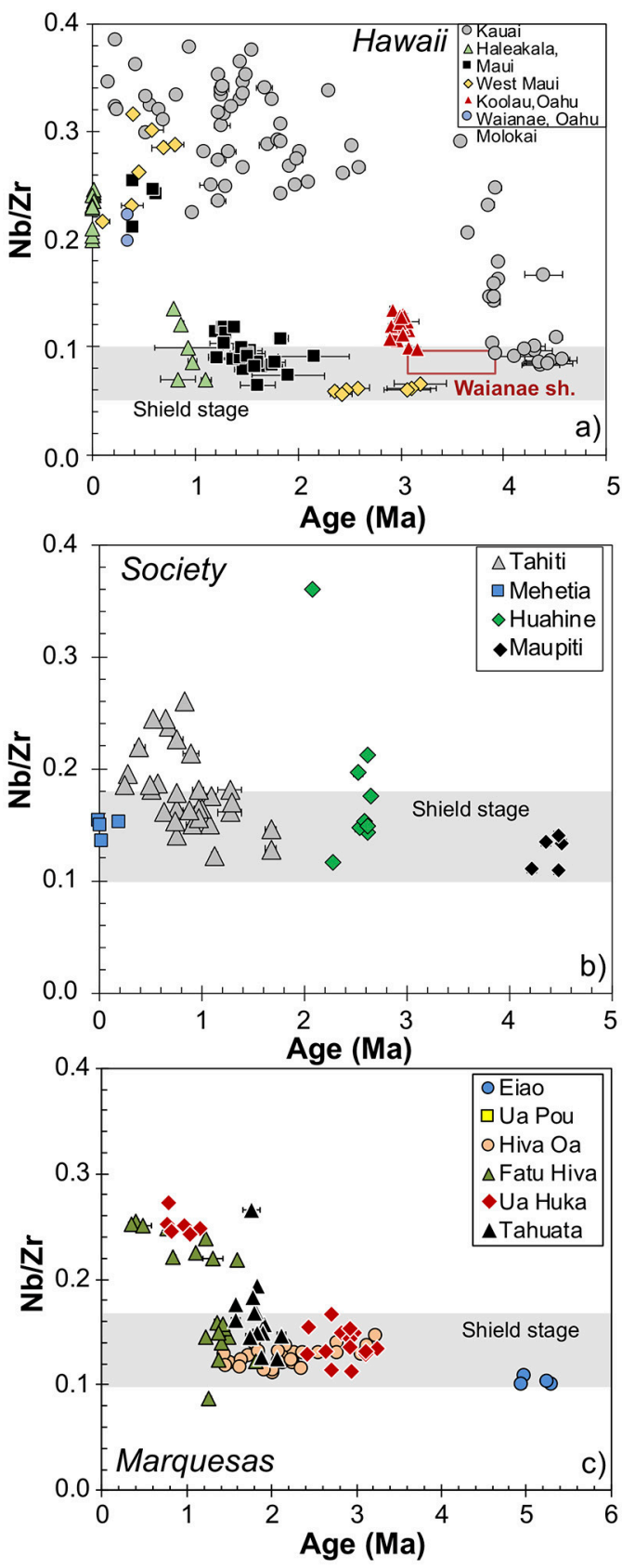

FIGURE 6 | Variation of the $\mathrm{Nb} / \mathrm{Zr}$ ratios in the lavas with age for the best-studied volcanoes of the (a) Hawaii, (b) Society, and (c) Marquesas hotspots. Note that error bars are shown for most ages but are typically smaller than the symbols. The chemical variation of the lavas with age implies changes in the magma formation and mantle source. The red box in (a) indicates the range of eruption ages and compositions of the shield lavas at Waianae volcano. Note also that there is considerable overlap between shield stage volcanism and later more enriched postshield or rejuvenated volcanism in Kaua'i, Tahiti, Huahine, Tahuata, and Fatu Hiva. Data sources can be found in the Supplementary Material.

of partial melting although only the Hawaiian hotspot shows voluminous tholeiitic shield stage basalts. The recurrent relatively high degrees of partial melting beneath thick lithospheric plates support the formation in a long-lived melting anomaly probably caused by thermal or chemical mantle plumes. The covariation of $\mathrm{SiO}_{2}$ and incompatible element ratios (Figures 3, 5) indicates that the degree of partial melting varies with source composition in agreement with melting of variably enriched mantle sources.

The different volcanoes of most hotspots show very similar compositions in their shield stages (Figures 2, 3) implying that the variation in major and incompatible element source compositions and melting process with time is relatively small although there are significant differences in terms of radiogenic isotope compositions (e.g., Abouchami et al., 2005; Payne et al., 2013). This can best be explained by thermally and compositionally homogenous melting zones in the different hotspots over time periods of several million years. Such a systematic homogeneity is especially observed at the Hawaiian shield volcanoes but the estimated volumes of the youngest volcanoes vary from $\sim 9,000 \mathrm{~km}^{3}$ for West Maui to $\sim 74,000$ $\mathrm{km}^{3}$ for Mauna Loa (Clague and Sherrod, 2014). Even if a significant variation of degree of eutectic melting may produce tholeiitic magmas, the incompatible element ratios would be variably diluted which is not observed. Thus, while the recurrent geochemical composition of shield tholeiites implies a constant degree of melting during the shield stage the magma production varies by a factor of 8 . This may imply that the erupted magma volume above mantle plumes may not be simply related to the degrees of partial melting.

The lavas from the Hawaiian hotspot indicate a larger variation in primitive magma compositions than those from the other Pacific hotspots (Figure 4). Experiments suggest that the large variation of $\mathrm{SiO}_{2}$ contents in Hawaiian primary magmas between 36 and 52 wt.\% requires low-degree melting of $\mathrm{CO}_{2}$ rich mantle (e.g., Brey and Green, 1975; Clague and Frey, 1982; Cousens and Clague, 2015) on the one hand, and melting of pyroxenite-rich mantle on the other hand (e.g., Hauri, 1996). In contrast, the other three hotspot magmas range from basanites, alkali basalts, to rare tholeiitic basalts (Figure 2) most of which have been produced experimentally by variable degrees of partial melting of peridotite bearing some $\mathrm{CO}_{2}$ (Takahashi and Kushiro, 1983; Hirose, 1997; Green et al., 2001; Dasgupta et al., 2007). This relatively restricted compositional variation of the mantle sources in the other three hotspots may indicate that $\mathrm{CO}_{2}$-rich components and pyroxenite are absent and the source probably mainly consists of garnet peridotite.

\section{Age Variation of Shield Stages}

The plume model predicts that the shield stage of the volcanoes should reflect the plate velocity and the width of the central plume melting zone. In the case of the hotspots beneath the old and thick Pacific Plate the width of the plume should be the most important parameter directly related to both composition and age of the erupted melts. The definition of the period of time for the shield stage of each volcano is difficult to establish because the beginning cannot be established due to volcano growth and rare samples from the preshield stages. Preshield lavas were sampled and age-dated at the Loihi, Kilauea, and Kohala volcanoes of the Hawaiian hotspot and are typically basanites and alkali basalts (Clague and Sherrod, 2014). As 
discussed above the preshield stages are poorly defined at the other hotspots and we suggest that early submarine stages of intraplate volcanism may have a different magmatic evolution compared to the Hawaiian volcanoes. Because of the unknown initiation of shield volcanism the age range observed in the compiled ages for shield stage lavas are minimum ages. The compiled data for the well-studied Hawaiian volcanoes Koolau, West Maui, and Kauai show relatively low $\mathrm{Nb} / \mathrm{Zr}$ ratios for $\sim 1$ million years (Figure 6) indicating that the shield stage of Hawaiian volcanoes may typically last $\sim 1$ million years, whereas earlier studies suggested relatively short shield stages $<0.5$ million years (Frey et al., 1990). The well-studied lavas from Tahiti and those from Hiva Oa, Tahuata, and Ua Huka in the Marquesas suggest that the shield stage of these volcanoes also lasted $\sim 1$ million years (Figure 6). The Pacific Plate moves with the same velocity of $\sim 10 \mathrm{~cm} / \mathrm{yr}$ across the Hawaii, Society and Marquesas plumes (Gripp and Gordon, 2002). Thus, the apparent similarity of the duration of the shield stage in the different hotspots indicates similar widths of $\sim 100 \mathrm{~km}$ for the central melting anomalies. This observation is surprising considering that the buoyancy fluxes and likely the temperatures are distinct between the different plumes (Davies, 1988; Sleep, 1990). The variation of magma compositions indicates that the degree of melting varies and, for example, the alkaline shield lavas of the Marquesas formed at lower degrees of melting than the tholeiites of Hawaii implying that the Hawaii plume has a higher temperature than the other plumes (Herzberg and Asimov, 2008). We thus conclude that the widths of the melting anomalies are not linked to the temperature of the plumes but may be rather be affected by the velocity of the plate and the resulting plume shear. The similarity in melting zone width may be due to the horizontal spreading of the ascending plume by the relatively fast Pacific Plate (Farnetani and Hofmann, 2010) that may affect plumes with lower buoyancy more than the strong Hawaiian plume. This also implies that there will be no simple correlation between duration of the respective volcanic stages and the physical properties of the plume. The occurrence of more enriched signatures in the Samoa, Marquesas and Society islands may largely reflect mantle heterogeneity due to the smaller buoyancy flux as compared to the Hawaiian mantle plume in which much of this heterogeneity may be overprinted by the extensive melting regime.

\section{The Transition From the Shield to the Postshield and Rejuvenated Stages}

Large geochemical differences between shield lavas occur at Samoa but some volcanoes of this hotspot appear to erupt very large volumes of postshield and rejuvenated lavas, too, probably reflecting the tectonic influence of the Tonga subduction zone on mantle melting (Natland, 1980; Konter and Jackson, 2012). Thus, the Samoan intraplate volcanism deviates from the more regular pattern of volcano evolution of the other Pacific hotspots. Hence, the Hawaiian model may not be easily applicable to other intraplate volcanoes. Toward the end of the shield stage, more enriched lavas with higher $\mathrm{Nb} / \mathrm{Zr}$ ratios are observed at West Maui and Kaua'i but also at Tahiti, Tahuata, and Fatu Hiva (Figure 6) implying that the formation of postshield magmas overlaps with that of the shield stage by up to 200 kyrs. This evolution has been described previously for Hawaiian volcanoes (Clague and Sherrod, 2014; Sinton et al., 2017), but seems to be a typical feature also observed in lavas from other Pacific hotspots. Interestingly, a few samples at Kauai, Tahuata, and Fatu Hiva suggest that the volcanoes erupt the most enriched lavas contemporaneously to the final shield and the postshield lavas (Figure 6). The variation of age and $\mathrm{Nb} / \mathrm{Zr}$ ratios displays a significant overlap of the lavas formed during the different stages and there appears to be a period toward the end of the shield stage when relatively $\mathrm{SiO}_{2}$-rich and less incompatible element-enriched lavas erupt parallel to more alkaline and enriched postshield stage lavas (Figure 6). This overlap requires at least two separate magma systems in the mantle feeding the eruptions at the top with limited mixing occurring in between the different ascent systems. The postshield magmas are typically more alkaline than the shield magmas and probably formed by lower degrees of partial melting. A numerical dynamic model of the Hawaiian plume (Farnetani and Hofmann, 2010) suggests that the postshield magmas represent deeper melts than the shield magmas which is in agreement with the lower $\mathrm{SiO}_{2}$ contents and higher $(\mathrm{Ce} / \mathrm{Yb})_{\mathrm{N}}$ of the melts (Figure 5). We conclude that the melting zone of many mantle plumes produces different melts for about 200 kyrs and that these magmas rise in separate systems to the surface. At a plate velocity of $10 \mathrm{~cm} / \mathrm{yr}$ this period of time suggests an $\sim 20 \mathrm{~km}$ wide zone of overlap in the melting region feeding the different magmas which will be on the scale of a single volcanic system.

\section{Putting the Hawaiian Model to a Test}

The compilation of the chemical and age data for the four Pacific hotspot lavas indicates that Hawaii is unusual in the chemical variation of the lavas (Figure 4), but that there are similar patterns of magma evolution from alkaline submarine preshield eruptions to relatively $\mathrm{SiO}_{2}$-rich shield lavas and then more alkaline postshield and rejuvenated lavas. Only Samoa seems to show a different evolution where the youngest submarine stage at Vailulu resembles that of subaerial shield stages at older volcanoes and where rejuvenated lavas appear to be extremely abundant. However, more data with better age resolution are required to test the applicability of the Hawaiian model at the Samoan volcanoes. In the well-studied Marquesas and Society hotspot volcanoes the change from shield to postshield and rejuvenated volcanism is comparable to that observed at Hawaiian volcanoes (Figure 6). The interpretation of the preshield volcanism is similarly complicated for Hawaii, Society, and Marquesas because this stage is mainly known from few samples from single submarine volcanoes without a clear relation to shield volcanism. We suggest that the Hawaiian model explains the observed systematic variation of magma composition with time as a reflection of variable degrees of partial melting due to movement of the plate across a plume.

Some inter-shield variability within the Marquesas, Society, and the Hawaiian island chain (Figure 3) can be observed between the islands of the northern- and islands of the southern groups (Abouchami et al., 2005; Payne et al., 2013). The physically different source components contribute to 
the formation of the shield volcanoes over small spatial distances of less than few km's (Pietruszka and Garcia, 1999) strongly supporting the complex and heterogeneous nature of plumes and their surrounding mantle material. The presence of tholeiitic, large degree melts during the shield stages may be restricted to large, stationary plume systems that preferentially have larger buoyancy fluxes leading to larger degrees of partial melting. On the other hand, the extremely enriched and $\mathrm{SiO}_{2}$-undersaturated melts of the Hawaiian rejuvenated magmas may indicate either more variable mantle sources or remelting of enriched sources by the extremely hot Hawaiian plume. We conclude that the evolution of ocean island volcanoes through distinct volcanological, petrological, and geochemical stages does not strictly follow the Hawaiian model and chemical variation is smaller but that the compositional changes between the different stages are clearly discernable.

\section{CONCLUSIONS AND OUTLOOK}

The limited age and compositional data of lavas from the Pacific hotspots reveal systematic variations of magma composition with age in most volcanoes where the late lavas are typically more enriched in incompatible elements and more alkaline than those of the shield stage. The Society and Marquesas hotspots show basanitic submarine volcanism apparently preceding the shield stage with alkali basaltic magmas. This variation most likely reflects the movement of the lithospheric plate across a thermal mantle plume forming a zoned melting anomaly with variable degrees of partial melting. However, more data with combined chemical and age constraints are required to better define the evolution of the intraplate magmatic systems. Existing data indicate that the shield stages of the well-studied volcanoes last about 1 million years and seem to similar for both strong and weak plumes. Because the velocity of the Pacific Plate is similar

\section{REFERENCES}

Abouchami, W., Hofmann, A. W., Galer, S. J. G., Frey, F. A., Eisele, J., and Feigenson, M. (2005). Lead isotopes reveal bilateral asymmetry and vertical continuity in the Hawaiian mantle plume. Nature 434, 851-856. doi: 10.1038/nature03402

Adam, C., Yoshida, M., Isse, T., Suetsugu, D., Fukao, Y., and Barruol, G. (2010). South Pacific hotspot swells dynamically supported by mantle flows. Geophys. Res. Lett. 37:L08302. doi: 10.1029/2010GL042534

Binard, N., Hékinian, R., Cheminée, J. L., and Stoffers, P. (1992). Styles of eruptive activity on intraplate volcanoes in the Society and Austral hot spot regions: bathymetry, petrology, and submersible observations. J. Geophys. Res. 97, 13999-14015. doi: 10.1029/92JB00692

Brey, G., and Green, D. R. (1975). The role of $\mathrm{CO}_{2}$ in the genesis of olivine melilitite. Contrib. Mineral. Petrol. 49, 93-103. doi: 10.1007/BF00373853

Chen, C.-Y., Frey, F. A., Garcia, M. O., Dalrymple, G. B., and Hart, S. R. (1991). The tholeiite to alkalic basalt transition at Haleakala Volcano, Maui, Hawaii. Contrib. Mineral. Petrol. 106, 183-200. doi: 10.1007/BF00306433

Clague, D.A., and Sherrod, D.R. (2014). "Growth and degradation of Hawaiian volcanoes," in Characteristics of Hawaiian Volcanoes, eds M. P. Poland, T. J. Takahashi, and C. M. Landowski (Washington, DC: U.S Geological Survey Professional Paper), 97-146. at the studied hotspots this implies similar sizes of the melting anomalies although the temperatures in the mantle plumes differ. The overlap of shield and postshield stage volcanism for up to 200 kyrs is also typical at different hotspots and indicates about $20 \mathrm{~km}$ wide transitional melting zone at the flank of the plume during which there are contemporaneous eruptions of both shield stage and postshield stage melts through distinctively different channels of ascent. More age and geochemical data of stratigraphically controlled samples are required from different volcanoes in order to understand the trends of magma evolution, melting processes, and mantle dynamics.

\section{AUTHOR CONTRIBUTIONS}

$\mathrm{CB}$ and $\mathrm{KH}$ compiled data, wrote the manuscript, and prepared the figures. FK worked on the initial data compilation and filtering and contributed ideas.

\section{ACKNOWLEDGMENTS}

We thank the editor Adriano Pimentel for inviting this contribution and for his patience during the completion of this manuscript. We acknowledge the helpful and constructive reviews by J. G. Shellnutt, I. E. M. Smith, and D. Geist that have considerably improved the quality of this work. CB acknowledges support by I. MacLeod. We acknowledge funding by the Deutsche Forschungsgemeinschaft (DFG) through grant BE4459/7-1.

\section{SUPPLEMENTARY MATERIAL}

The Supplementary Material for this article can be found online at: https://www.frontiersin.org/articles/10.3389/feart. 2018.00242/full\#supplementary-material

Clague, D. A. (1987). Hawaiian xenolith populations, magma supply rates, and development of magma chambers. Bull. Volcanol. 49, 577-587. doi: 10.1007/BF01079963

Clague, D. A., and Dalrymple, G. B. (1987). The Hawaiian-emperor volcanic chain Part I. geologic evolution. U.S. Geol. Surv. Prof. Paper. 1350, 5-54.

Clague, D. A., and Dalrymple, G. B. (1988). Age and petrology of alkalic postshield and rejuvenated-stage lava from Kauai, Hawaii. Contrib. Mineral. Petrol. 99, 202-218. doi: 10.1007/BF00371461

Clague, D. A., and Frey, F. A. (1982). Petrology and trace element geochemistry of the Honolulu Volcanics, Oahu: implications for the oceanic mantle below Hawaii. J. Petrol. 23, 447-504. doi: 10.1093/petrology/ 23.3.447

Clouard, V., and Bonneville, A. (2005). "Ages of seamounts, islands, and plateaus on the Pacific plate," in Plates, Plumes, and Paradigms, eds G. R. Foulger, J. H. Natland, D. C. Presnall, and D. L. Anderson (Boulder, CO: Geological Society of America Special Paper), 71-90.

Courtillot, V., Davaille, A., Besse, J., and Stock, J. (2003). Three distinct types of hotspots in the Earth's mantle. Earth Planet. Sci. Lett. 205, 295-308. doi: 10.1016/S0012-821X(02)01048-8

Cousens, B. L., and Clague, D. A. (2015). Shield to rejuvenated stage volcanism on Kauai and Niihau, Hawaiian Islands. J. Petrol. 56, 1547-1584. doi: 10.1093/petrology/egv045 
Dasgupta, R., Hirschmann, M. M., and Smith, N. D. (2007). Partial melting experiments of peridotite $+\mathrm{CO}_{2}$ at $3 \mathrm{GPa}$ and genesis of alkalic ocean island basalts. J. Petrol. 48, 2093-2124. doi: 10.1093/petrology/egm053

Davies, G. F. (1988). Ocean bathymetry and mantle convection 1. Large-scale flow and hotspots. J. Geophys. Res. 93, 10467-10480. doi: 10.1029/JB093iB09p10467

Desonie, D. L., Duncan, R. A., and Natland, J. H. (1993). Temporal and geochemical variability of volcanic products of the Marquesas Hotspot. J. Geophys. Res. 98, 17649-17666. doi: 10.1029/93JB01562

Detrick, R. S., von Herzen, R. P., Crough, S. T., Epp, D., and Fehn, U. (1981). Heat flow on the Hawaiian Swell and lithospheric reheating. Nature 292, 142-143. doi: $10.1038 / 292142 \mathrm{a} 0$

Devey, C. W., Albarède, F., Cheminée, J.-L., Michard, A., Mühe, R., and Stoffers, P. (1990). Active submarine volcanism on the Society Hotspot Swell (west Pacific): a geochemical study. J. Geophys. Res. 95, 5049-5066. doi: 10.1029/JB095iB04p05049

Devey, C. W., Lackschewitz, K. S., Mertz, D. F., Bourdon, B., Cheminée, J.-L., Dubois, J., et al. (2003). Giving birth to hotspot volcanoes: distribution and composition of young seamounts from the seafloor near Tahiti and Pitcairn islands. Geology 31, 395-398. doi: 10.1130/0091-7613(2003)031andlt;0395:GBTHVDandgt;2.0.CO;2

Duncan, R. A., Fisk, M. R., White, W. M., and Nielsen, R. L. (1994). Tahiti: geochemical evolution of a French Polynesian volcano. J. Geophys. Res. 99, 24341-24357. doi: 10.1029/94JB00991

Duncan, R. A., and Richards, M. A. (1991). Hotspots, mantle plumes, flood basalts, and true polar wander. Rev. Geophys. 29, 31-50. doi: 10.1029/90RG02372

Dymond, J. (1975). K-Ar ages of Tahiti and Moorea, society Islands, and implications for the hot-spot model. Geology 3, 236-240. doi: 10.1130/0091-7613(1975)3andlt;236:KAOTAMandgt;2.0.CO;2

Farnetani, C. G., and Hofmann, A. W. (2010). Dynamics and internal structure of the Hawaiian plume. Earth Planet. Sci. Lett. 295, 231-240. doi: $10.1016 /$ j.epsl.2010.04.005

French, S. W., and Romanowicz, B. (2015). Broad plumes rooted at the base of the Earth's mantle beneath major hotspots. Nature 525, 95-99. doi: $10.1038 /$ nature14876

Frey, F. A., Garcia, M. O., and Roden, M. F. (1994). Geochemical characteristics of Koolau Volcano: implications of intershield geochemical differences among Hawaiian volcanoes. Geochim. Cosmochim. Acta 58, 1441-1462. doi: 10.1016/0016-7037(94)90548-7

Frey, F. A., Garcia, M. O., Wise, W. S., Kennedy, A., Gurriet, P., and Albarède, F. (1991). The evolution of Mauna Kea volcano, Hawaii: petrogenesis of tholeiitic and alkalic basalts. J. Geophys. Res. 96, 14347-14375. doi: 10.1029/91JB00940

Frey, F. A., Green, D. H., and Roy, S. D. (1978). Integrated models of basalt petrogenesis: a study of quartz tholeiites to olivine melilitites from south eastern Australia utilizing geochemical and experimental petrological data. J. Petrol. 19, 463-513. doi: 10.1093/petrology/19.3.463

Frey, F. A., Wise, W. S., Garcia, M. O., West, H., Kwon, S.-T., and Kennedy, A. (1990). Evolution of Mauna Kea volcano, Hawaii: petrologic and geochemical constraints on postshield volcanism. J. Geophys. Res. 95, 1271-1300. doi: 10.1029/JB095iB02p01271

Garcia, M. O., Swinnard, L., Weis, D., Greene, A. R., Tagami, T., Sano, H., et al. (2010). Petrology, geochemistry and geochronology of Kaua'i lavas over 4.5 Myr: implications for the origin of rejuvenated volcanism and the evolution of the Hawaiian Plume. J. Petrol. 51, 1507-1540. doi: 10.1093/petrology/egq027

Green, D. H., Falloon, T. J., Eggins, S. M., and Yaxley, G. M. (2001). Primary magmas and mantle temperatures. Eur. J. Mineral. 13, 437-451. doi: 10.1127/0935-1221/2001/0013-0437

Gripp, A. E., and Gordon, R. G. (2002). Young tracks of hotspots and current plate velocities. Geophys. J. Int. 150, 321-361. doi: 10.1046/j.1365-246X.2002.01627.x

Guillou, H., Maury, R. C., Blais, S., Cotten, J., Legendre, C., Guille, G., et al. (2005). Age progression along the Society hotspot chain (French Polynesia) based on new unspiked K-Ar ages. Bull. Soc. Geol. Fr. 176, 135-150. doi: 10.2113/176.2.135

Guillou, H., Maury, R. C., Guille, G., Chauvel, C., Rossi, P., Pallares, C., et al. (2014). Volcanic successions in Marquesas eruptive centers: a departure from the Hawaiian model. J. Volcanol. Geotherm. Res. 276, 173-188. doi: $10.1016 /$ j.jvolgeores.2013.12.003
Hart, S. R., Staudigel, H., Koppers, A. A. P., Blusztajn, J., Baker, E. T., Workman, R., et al. (2000). Vailulu'u undersea volcano: the new Samoa. Geochem. Geophys. Geosyst. 1:1056. doi: 10.1029/2000GC000108

Hauri, E. H. (1996). Major-element variability in the Hawaiian mantle plume. Nature 382, 415-419. doi: 10.1038/382415a0

Herzberg, C., and Asimov, P. D. (2008). Petrology of some oceanic island basalts: PRIMELT2.XLS software for primary magma calculation. Geochem. Geophys. Geosyst. 9:Q09001. doi: 10.1029/2008GC002057

Hildenbrand, A., Gillot, P.-Y., and LeRoy, I. (2004). Volcano-tectonic and geochemical evolution of an oceanic intra-plate volcano: TahitiNui (French Polynesia). Earth Planet. Sci. Lett. 217, 349-365. doi: 10.1016/S0012-821X(03)00599-5

Hirose, K. (1997). Partial melt compositions of carbonated peridotite at $3 \mathrm{GPa}$ and role of $\mathrm{CO}_{2}$ in alkali-basalt magma generation. Geophys. Res. Lett. 24, 2837-2840. doi: 10.1029/97GL02956

Hofmann, A. W. (2003). Sampling Mantle Heterogeneity Through Oceanic Basalts: Isotopes and Trace Elements, Treatise on Geochemistry. Amsterdam: Elsevier. doi: 10.1016/B0-08-043751-6/02123-X

Hofmann, A. W., and Farnetani, C. G. (2013). Two views of Hawaiian plume structure. Geochem. Geophys. Geosyst. 14, 5308-5322. doi: 10.1002/2013GC004942

Jackson, M. G., and Dasgupta, R. (2008). Compositions of HIMU, EM1, and EM2 from global trends between radiogenic isotopes and major elements in ocean island basalts. Earth Planet. Sci. Lett. 276, 175-186. doi: 10.1016/j.epsl.2008.09.023

Jellinek, A. M., and Manga, M. (2004). Links between long-lived hot spots, mantle plumes, D", and plate tectonics. Rev. Geophys. 42:RG3002. doi: $10.1029 / 2003 R G 000144$

Konter, J. G., and Jackson, M. G. (2012). Large volumes of rejuvenated volcanism in Samoa: evidence supporting a tectonic influence on late-stage volcanism. Geochem. Geophys. Geosyst. 13:Q0AM04. doi: 10.1029/2011GC003974

Koppers, A. A. P., Russell, J. A., Jackson, M. G., Konter, J. G., Staudigel, H., and Hart, S. R. (2008). Samoa reinstated as a primary hotspot trail. Geology 36, 435-438. doi: 10.1130/G24630A.1

Koppers, A. A. P., Russell, J. A., Roberts, J., Jackson, M. G., Konter, J. G., Wright, D. J., et al. (2011). Age systematics of two young en echelon Samoan volcanic trails. Geochem. Geophys. Geosyst. 12:Q07025. doi: 10.1029/2010GC0 03438

Le Bas, M. J., Le Maitre, R. W., Streckeisen, A., and Zanettin, B. (1986). A chemical classification of volcanic rocks based on the total alkali-silica diagram. J. Petrol. 27, 745-750. doi: 10.1093/petrology/27.3.745

Liu, M., and Chase, C. G. (1991). Evolution of Hawaiian basalts: a hotspot melting model. Earth Planet. Sci. Lett. 104, 151-165. doi: 10.1016/0012-821X(91)90201-R

Macdonald, G. A., and Katsura, T. (1964). Chemical composition of Hawaiian lavas. J. Petrol. 5, 82-133. doi: 10.1093/petrology/5.1.82

McDougall, I. (2010). Age of volcanism and its migration in the Samoa Islands. Geol. Mag. 147, 705-717. doi: 10.1017/S0016756810000038

McDougall, I., and Duncan, R. A. (1980). Linear volcanic chains-recording plate motions? Tectonophys 63, 275-295. doi: 10.1016/0040-1951(80)90117-1

Moore, J. G., Clague, D. A., and Normark, W. R. (1982). Diverse basalt types from Loihi seamount, Hawaii. Geology 10, 88-92. doi: 10.1130/0091-7613(1982)10<88:DBTFLS >2.0.CO;2

Morgan, W. J. (1971). Convection plumes in the lower mantle. Nature 230, 42-43. doi: $10.1038 / 230042 \mathrm{a} 0$

Morgan, W. J. (1972). Deep mantle convection plumes and plate motions. Am. Ass. Petrol. Geol. Mem. 56, 203-213.

Müller, R. D., Sdrolias, M., Gaina, C., and Roest, W. R. (2008). Age, spreading rates, and spreading asymmetry of the world's ocean crust. Geochem. Geophys. Geosys. 9:Q04006. doi: 10.1029/2007GC001743

Natland, J. (1980). The progression of volcanism in the Samoan linear volcanic chain. Am. J. Sci. 280, 709-735.

O'Connor, J., Steinberger, B., Regelous, M., Koppers, A., Wijbrans, J., Haase, K., et al. (2013). Constraints on past plate and mantle motion from new ages for the Hawaiian-Emperor seamount chain. Geochem. Geophys. Geosyst.14, 4564-4584. doi: 10.1002/ggge.20267 
Payne, J. A., Jackson, M. G., and Hall, P. S. (2013). Parallel volcano trends and geochemical asymmetry of the society Islands hotspot track. Geology 41, 19-22. doi: $10.1130 / \mathrm{G} 33273.1$

Pietruszka, A. J., and Garcia, M. O. (1999). A rapid fluctuation in the mantle source and melting history of Kilauea volcano inferred from the geochemistry of its historical summit lavas (1790-1982). J. Petrol. 40, 1321-1342. doi: 10.1093/petroj/40.8.1321

Putirka, K. D., Perfit, M., Ryerson, F. J., and Jackson, M. G. (2007). Ambient and excess mantle temperatures, olivine thermometry, and active vs. passive upwelling. Chem. Geol. 241, 177-206. doi: 10.1016/j.chemgeo.2007. 01.014

Révillon, S., Guillou, H., Maury, R. C., Chauvel, C., Aslanian, D., Pelleter, E., et al. (2017). Young marquesas volcanism finally located. Lithos 294-295, 356-361. doi: 10.1016/j.lithos.2017.10.013

Sharp, W. D., and Clague, D. A. (2006). 50-Ma initiation of Hawaiian-Emperor bend records major change in Pacific Plate motion. Science 313, 1281-1284. doi: 10.1126/science.1128489

Sinton, J. M., Eason, D. E., and Duncan, R. A. (2017). Volcanic evolution of Moloka'i, Hawai'i: implications for the shield to postshield transition in Hawaiian volcanoes. J. Volcanol. Geotherm. Res. 340, 30-51. doi: 10.1016/j.jvolgeores.2017.04.011

Sleep, N. H. (1990). Hotspots and mantle plumes: some phenomenology. J. Geophys. Res. 95, 6715-6736. doi: 10.1029/JB095iB05p 06715

Strak, V., and Schellart, W. P. (2018). A subduction and mantle plume origin for Samoan volcanism. Sci. Rep. 8:10424. doi: 10.1038/s41598-018-28267-3

Takahashi, E., and Kushiro, I. (1983). Melting of a dry peridotite at high pressures and basalt magma genesis. Am. Mineral. 68, 859-879.

Talandier, J., and Okal, E. A. (1984). New survey of Macdonald Seamount, south Central Pacific, following volcanoseismic acitivity, 1977-1983. Geophys. Res. Lett. 11, 813-816. doi: 10.1029/GL011i009p 00813
Tarduno, J. A., Duncan, R. A., Scholl, D. W., Cottrell, R. D., Steinberger, B., Thordarson, T., et al. (2003). The Emperor Seamounts: southward motion of the Hawaiian hotspot plume in Earth's mantle. Science 301, 1064-1069. doi: $10.1126 /$ science. 1086442

Thordarson, T., and Garcia, M. O. (2018). Variance of the flexure model predictions with rejuvenated volcanism at Kilauea Point, Kaua'i, Hawai'i. Front. Earth Sci. 6:121. doi: 10.3389/feart.2018.00121

Uto, K., Yamamoto, Y., Sudo, M., Uchiumi, S., Ishizuka, O., Kogiso, T., et al. (2007). New K-Ar ages of the Society Islands, French Polynesia, and implications for the Society hotspot feature. Earth Planets Space 59, 879-885. doi: 10.1186/BF03352750

Watson, S., and McKenzie, D. (1991). Melt generation by plumes: a study of Hawaiian volcanism. J. Petrol. 32, 501-537. doi: 10.1093/petrology/32.3.501

White, W. M. (2010). Oceanic island basalts and mantle plumes: the geochemical perspective. Ann. Rev. Earth Planet. Sci. 38, 133-160. doi: 10.1146/annurev-earth-040809-152450

Wilson, J. T. (1963). A possible origin of the Hawaiian Islands. Can. J. Earth Sci. 41, 863-870. doi: 10.1139/p63-094

Woodhead, J. D. (1992). Temporal geochemical evolution in oceanic intraplate volcanics: a case study from the Marquesas (French Polynesia) and comparison with other hotspots. Contrib. Mineral. Petrol. 111, 458-467. doi: 10.1007/BF00320901

Conflict of Interest Statement: The authors declare that the research was conducted in the absence of any commercial or financial relationships that could be construed as a potential conflict of interest.

Copyright (C) 2019 Haase, Beier and Kemner. This is an open-access article distributed under the terms of the Creative Commons Attribution License (CC BY). The use, distribution or reproduction in other forums is permitted, provided the original author(s) and the copyright owner(s) are credited and that the original publication in this journal is cited, in accordance with accepted academic practice. No use, distribution or reproduction is permitted which does not comply with these terms. 